\title{
Time lapse chemical fertilizer monitoring in agriculture sandy soil
}

\author{
*N. Islami; S. Taib; I. Yusoff; A. Abdul Ghani \\ Department of Geology, Faculty of Sciences, University of Malaya, 50603 Kuala Lumpur, Malaysia \\ Received 23 December 2011; revised 27 June 2011; accepted 13 August 2011; available online 1 September 2011
}

\begin{abstract}
Geoelectrical resistivity, hydrogeochemical and soil properties analysis methods were used for chemical fertilizer monitoring in sandy soil at a palm oil plantation in Machang, Malaysia. The time lapse monitoring was done using these methods five times within a three-month period. The hydrogeochemical analysis was conducted over three auger holes to a depth of $1 \mathrm{~m}$ and sampled at $25 \mathrm{~cm}$ intervals. Chemical fertilizer was applied to the $21 \mathrm{x}$ $21 \mathrm{~m}^{2}$ area after the first data set measurement. The areas outside of this fertilized zone are considered a nonfertilized zone. The other four data sets were acquired at about equal time intervals, thus giving a four-post fertilization data set. The hydrogeochemical measurements indicate that the cations content are relatively similar for every time lapse measurement. However, relatively higher changes of anions content occur at the surface level to a depth of $1 \mathrm{~m}$. The nitrate concentration above the limit for safe human consumption as it returns to the initial value about 100 days after fertilization. The geoelectrical model prior to fertilization showed similar resistivity values at near surface to a depth of about $75 \mathrm{~cm}$ with no significant occurrences of low resistivity values. Lower resistivity values were obtained during the second, third, fourth and fifth measurements within the chemically fertilized zone. In the last measurement, the resistivity values in the fertilized zone are almost similar to the nonfertilized zone. This indicates that the contaminant has dissolved into the surrounding environment within this time period.
\end{abstract}

Keywords: Fertilizer; Geoelectrical resistivity; Hydrogeochemical; Nitrate; Soil property

\section{INTRODUCTION}

The palm oil plantation is the main agriculture establishment in the study area. The groundwater pollution of high agricultural activity is a consequence of farming practices using large quantities of fertilizers. The impact of these practices on the pollution of groundwater reported by Bernhard et al. (1992) and Singh et al. (1995).

In many parts of the word, chemical fertilizers (Yang et al., 2006) are rigorously used to enhance the agricultural establishment. It includes the palm oil plantation, where fertilization is conducted every two months using fertilizers of different chemical content (refer to personal conversation with farming supervisor). At the beginning of the year, $400 \mathrm{~kg}$ of urea with $60 \%$ nitrogen is used for a two ha palm oil plantation. Two months after that, another fertilizer with $15 \%$ nitrogen, $30 \%$ phosphorus and $55 \%$ potassium (NPK) is applied to further improve the production of palm. This process is repeated in the middle of the same year and continues until the end of the year. In

*Corresponding Author Email: nris@um.edu.my Tel.: +6037 9674 152; Fax: +6037 6975149 total, at least $800 \mathrm{~kg}$ of urea are used for the fertilization of palm trees in a two ha area per year.

The contaminant (especially nitrate) leaching from agricultural soils has been widely studied (Saadi and Maslouhi, 2003; Almasri and Kaluarachchi, 2004; Zhang et al., 2009). Human activities, including the application of chemical fertilizers in agriculture, cause the emission of nitrate into groundwater (Mahvi et al., 2005; Atafar et al., 2010). In Kelantan, studies of the nitrate contamination of shallow aquifers using integrated methods of geoelectrical, hydrogeochemical and soil property analysis have been carried out by Islami et al. (2010b), which relatively higher nitrate concentrations found in the areas with high fertilization activities. Islami (2010a) reported that geoelectrical resistivity value at the near surface in the fertilized area were lower than in the non-fertilized area. The impact of residual nitrate and chloride on the geoelectrical resistivity reading in areas treated with urea for a long period has been also reported by Islami (2010a). Obire et al. (2008) show that fertilizer introduction to the land has a negative impact on the quality of groundwater. In conjunction 
with subsurface investigation, some pioneering work using the geoelectrical resistivity imaging technique was carried out by Barker (1981), Overmeeren van and Ritsema (1988), Griffiths et al. (1990), Noel and Walker (1990), Griffiths and Barker (1993). The usefulness of this method for solving a number of geo-environmental problems has been shown by Reynolds (1997), Loke (1999), Abdul Nassir et al. (2000) and Baharuddin et al. (2009), with different case studies. However, no work has been done in the application of the geoelectrical resistivity imaging to monitor chemical fertilizers in the agricultural area with certain soil conditions. Moreover, a geoelectrical imaging survey rarely has been combined with laboratory measurements of soil water samples taken from the investigated site so that one can have a better guide to interpretation of the field values. The main objective of this paper is to monitor the chemical fertilizer in the subsurface with time in the vadose zone using geoelectrical resistivity and hydrogeochemical measurements supported by soil properties analysis. The changes amount of fertilizers in the pore soil to the geoelectrical resistivity reading, and discussion on nitrate leaching and its movement in the vadose zone of sandy soil, also were studied. The study on chemical fertilizer monitoring in the agriculture area is important due to the main water resources in this area are coming from the shallow groundwater extracted from conventional well. The study was carried out in April to September 2009. Soil and water samples collected from the field were analysed and interpreted at a hydrochemical laboratory, while geoelectrical resistivity data was processed and interpreted in the geophysical laboratory at the University of Malaya, Kuala Lumpur, Malaysia.

\section{Geology of study area}

The study site is located about $35 \mathrm{~km}$ in land from Kota Bharu, the capital of Kelantan State, Malaysia. Kelantan River and a high hill can be found around 4 $\mathrm{km}$ on the west and east side, respectively. The hill is a part of the Boundary Range Composite Batholith. It consists of two major components, the Machang Batholith which is about $100 \times 20 \mathrm{~km}$, with the smaller Kerai Batholith situated on is western flank (Cobbing and Pitfield, 1992). Around the hill, a lot of exposed granite can be found especially at Sungai Buluh Quarry (about $4 \mathrm{~km}$ from the study area). The study area is covered with Quaternary sediments overlying granite bedrock. It is drained mainly by short rivers and streams which flow into the South China Sea. The thickness of the Quaternary deposits varies from $20 \mathrm{~m}$ inland to about $200 \mathrm{~m}$ near the coast. The loose quaternary sediments consist of alternating layers of coarse gravels to silts or mixtures of the two (Saim, 1999). Fig. 1 shows the location map of the research area. The RSO West Malaysia and Kertau 1946 are used as the coordinate system and datum in the map respectively.

\section{MATERIALS AND METHODS}

Time lapse chemical monitoring was done at different time survey periods under a "natural schema condition", which means that all the processes were conditioned by natural processes includings watering process by rainfall, undisturbed biological habitat and chemical fertilizer application by recurrent schema (Table 1).

An unproductive site of an old palm oil plantation in Kampung Tok Bok, Machang, was chosen for the investigation due to the area had not had any chemical fertilizer introduced for around 10 months before the survey was done. If the survey was done in the productive palm oil plantation, it would be very difficult to control which one of the fertilizer applications to monitor as the fertilizing activities continue.

The survey specification setup is given in Fig. 1 . The chemical monitoring was performed within the three months from 3 May to 3 August, 2009. This time frame was chosen based on the rainfall distribution in the area which rainfall occurs at an average amount within this period every year, making it representative of the average water input in this area. The maximum and minimum rainfall happen around NovemberDecember and February-March, respectively (MMD, 2009). The first, second, third, fourth, and fifth surveys refer to monitoring-1, monitoring-2, monitoring-3, monitoring-4, and monitoring-5, respectively. The first survey (monitoring-1) was done before the chemical fertilizer was introduced to the land. After the data set was completed in monitoring-1, the chemical fertilizer (urea) was distributed. Urea has the highest nitrogen content among the fertilizers. Thirteen $\mathrm{kg}$ of urea was distributed over the whole fertilizer zone (Fig. 1). The total of its weight was equal to $600 \mathrm{~kg}$ per 2 ha. The distribution of chemical fertilizer used was by the "natural schema condition". It was distributed by hand and approximately covered all the area with equal intensity. 


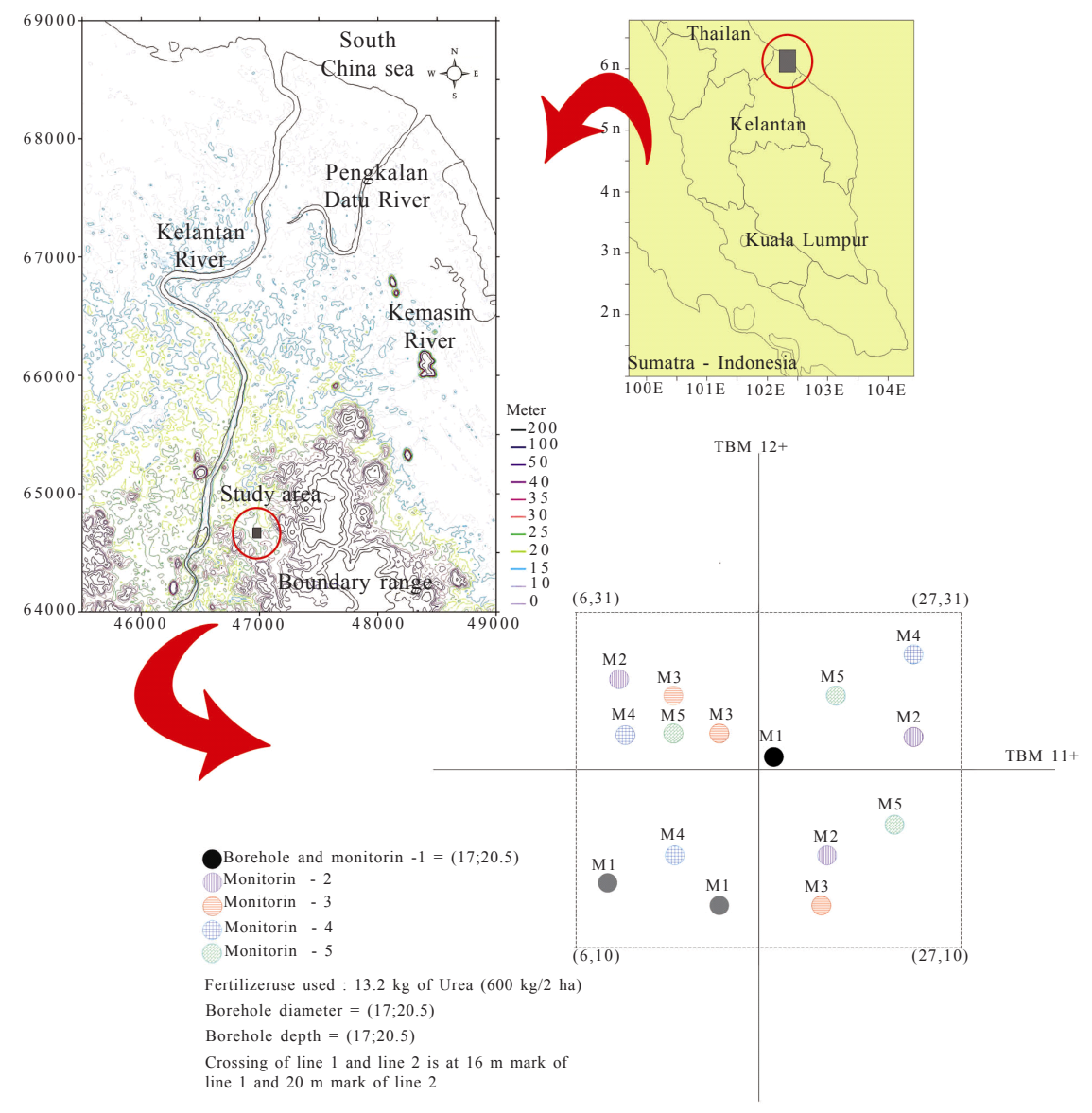

Fig. 1: Location map and field set up

Table 1: Fertilization scheme of palm oil plantation for tree more than 12 year old. The data was derived from the palm oil plantation supervisor

\begin{tabular}{|c|c|c|c|c|}
\hline No. & Month & Fertilizer types & Content & Amount per 2 ha \\
\hline 2 & February & NPK & $\mathrm{N}(15 \%), \mathrm{P}, \mathrm{K}$ & $600 \mathrm{~kg}$ \\
\hline 3 & April & Urea & Nitrogen $(60 \%)$ & $600 \mathrm{~kg}$ \\
\hline 4 & August & NPK & $\mathrm{N}(15 \%), \mathrm{P}, \mathrm{K}$ & $600 \mathrm{~kg}$ \\
\hline 4 & October & Urea & Nitrogen $(60 \%)$ & $600 \mathrm{~kg}$ \\
\hline 5 & December & Dolomite & Dolomite & $300 \mathrm{~kg}$ \\
\hline 6 & When needed & $\mathrm{KCl}$ & $\mathrm{KCl}$ & $300 \mathrm{~kg}$ \\
\hline 7 & Anytime & Farmyard manure & Mixture & As available \\
\hline
\end{tabular}

Several methods of investigation were used, including soil properties analysis, hydrogeochemical analysis and 2D geoelectrical resistivity imaging survey.

\section{Soil properties analysis}

In each survey, soil samples were collected for measuring the moisture content. Soil samples were 
taken from three holes (Fig. 1). Each hole was sampled from a depth of $0-1 \mathrm{~m}$ at $25 \mathrm{~cm}$ intervals. A gravimetric method (Black, 1965) was adopted to measure the moisture content. In this method, soil needs to be weighed before the drying stage. The sample and its container were heated in an oven at $105^{\circ} \mathrm{C}$ for $24 \mathrm{~h}$ to achieve stabilisation mass at constant value (without water content). Weight reduction as gravimetrical soil moisture content then was estimated.

Grain size distribution and hydraulic conductivity at shallow depths above water level were measured and reported by Islami (2009a). Grain size distribution and hydraulic conductivity data were needed to understand the soil characters of the area (Das, 2001).

\section{Hydrogeohemical analysis}

To analyse the chemical content of the soil water in the vadose zone, the samples had to be extracted directly from the soil. Soil water was sampled at $0 \mathrm{~m}$, $0.25 \mathrm{~m}, 0.50 \mathrm{~m}, 0.75 \mathrm{~m}$ and $1 \mathrm{~m}$ depths for three random locations (Fig. 1) using a 1900 Soil Water Samplers (manufactured by Soilmoisture Equipment Corp, USA). Three soil water samples were merged into a plastic bottle of $40 \mathrm{~mL}$ for each depth and labelled regarding the depth. Because the water sample was less than 25 $\mathrm{mL}$ for each sampling depth, the water sample was diluted with pure water to become 50:50 in their composition. Subsequently, the soil's water samples were kept in plastic bottles and maintained at a temperature of $4{ }^{\circ} \mathrm{C}$. The samples were analysed in the hydrogeochemical lab using Ion chromatography (IC) and Inductively coupled plasma (ICP) two days after the samples were collected.

\section{Geoelectrical resistivity imaging survey}

The 2D geoelectrical resistivity imaging surveys were performed at the site using the ABEM Terrameter SAS4000 resistivity meter. The Wenner arrays were used on two lines within each survey with $1 \mathrm{~m}$ of the electrode spacing. The total profile length was $40 \mathrm{~m}$. It was very difficult to carry out the survey with gridding lines due to the field condition. There were palm oil trees at every $6 \mathrm{~m}$ and presence of swales $(0.3 \mathrm{~m}$ depth, $1.5 \mathrm{~m}$ wide and around $7 \mathrm{~m}$ long) at every seven rows of palm oil tree intervals. Processing of the data was achieved by a tomographic inversion scheme using the software RES2DINV (Loke and Barker, 1996; Loke, 2007). In this scheme, true resistivity distribution in the subsurface is obtained by a linearized least-squares inversion of apparent resistivity pseudosections acquired along profiles.

\section{RESULTS AND DISCUSSION}

Soil grain size and hydraulic conductivity characteristics

The grain size distribution and hydraulic conductivity data obtained from a previous study (Islami, 2010a) indicated that the soil character is poor for aquifers in the semi-pervious category (Bear, 1972).

\section{Soil moisture content}

The highest amount of moisture content can be found on the surface level (Table 2). The moisture content in monitoring-1 decreases with depth. A similar decreasing trend also can be found in monitoring-2, monitoring-3, monitoring-4 and monitoring-5. Soil moisture content was influenced by the amount of rainfall and interval time before the soil was taken. Decreasing of moisture content with depth is due to the increase of gravel and sand-sized grains content with depth (Islami, 2010a). Generally, the moisture content decreases with depth for all monitoring.

\section{Extracted soil water chemical content}

Table 2 shows the chemical results of the extracted soil water contents for all monitoring. In monitoring-1, cation content ranges from 0 to $10.78 \mathrm{mg} / \mathrm{L}$. The highest cations content is $\mathrm{Ca}(10.78 \mathrm{mg} / \mathrm{L})$ at $50 \mathrm{~cm}$ of sampling depth. $\mathrm{K}, \mathrm{Ca}$ and $\mathrm{Na}$ are the dominant cations contents which have an average of $4.58 \mathrm{mg} / \mathrm{L}, 7.42 \mathrm{mg} / \mathrm{L}$ and $6.40 \mathrm{mg} / \mathrm{L}$, respectively, while $\mathrm{Mg}, \mathrm{Pb}, \mathrm{Cd}$ se $\mathrm{Mn}, \mathrm{Cu}$, $\mathrm{Zn}$, Fe, As concentrations have the average concentration less than $2 \mathrm{mg} / \mathrm{L}$. The cations concentration do not show any specific trend from the surface level to a depth of $100 \mathrm{~cm}$. Almost the maximum cation concentration appears at the surface level to a depth of $25 \mathrm{~cm}$; the other researcher also found higher nitrate concentration at the near surface (Kaushal et al., 2005; Oelmann et al., 2007; Mirjat et al., 2008; Islami, 2010a). This is due to the source of cation and anion concentration at the near surface is mainly from the fertilization activities. However, all cation contents lie within the accepted limits for human consumption (WHO, 1984).

For anion content, chloride and nitrate concentrations are observed to be the highest at the surface level. Nitrate concentration decreases with 


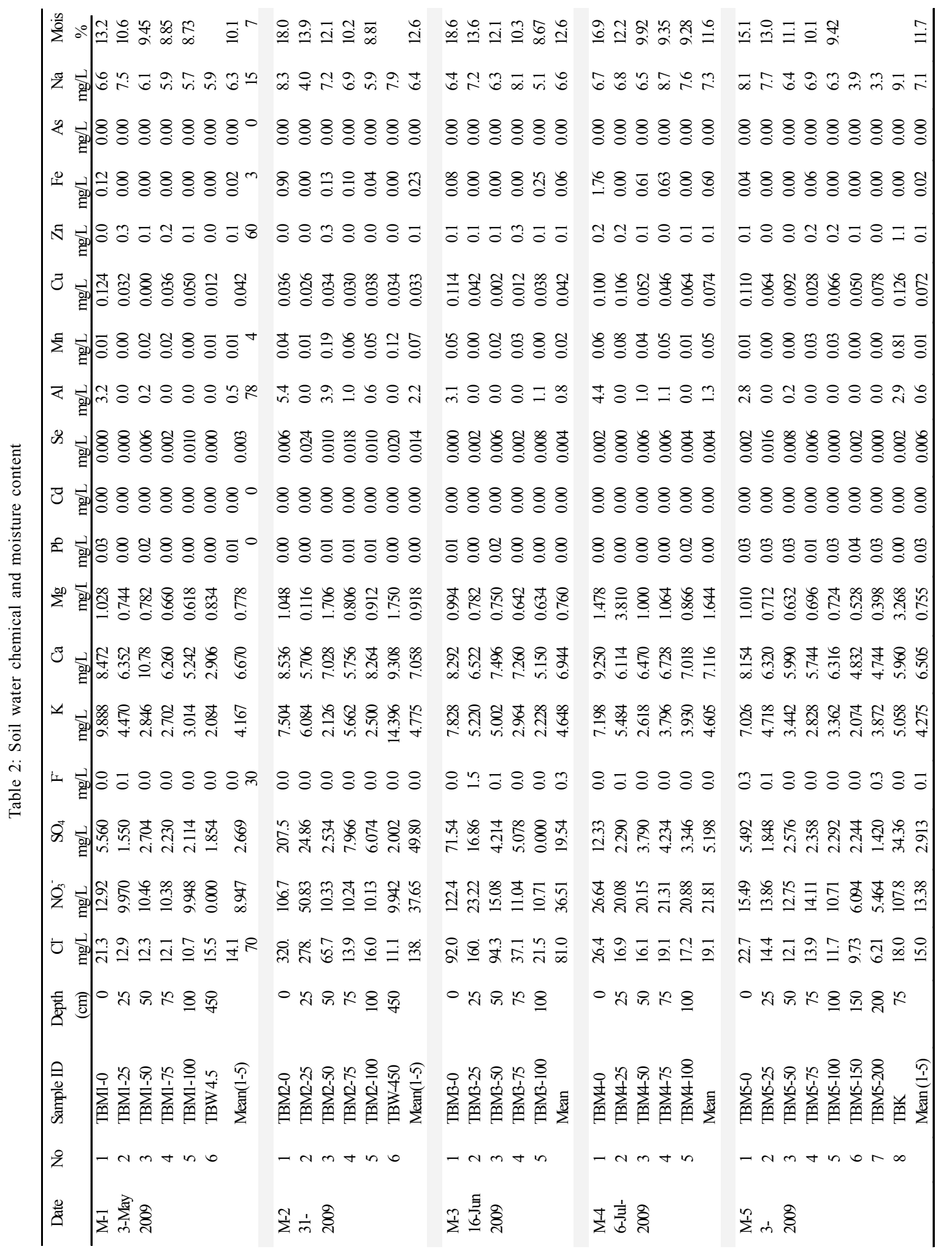


depth, except at the depth of $25 \mathrm{~cm}$. Meanwhile, the chloride concentration decreases with depth until a depth of $100 \mathrm{~cm}$. Average chloride and nitrate concentrations from the surface level until a depth of $100 \mathrm{~cm}$ are $13.9 \mathrm{mg} / \mathrm{L}$ and $10.74 \mathrm{mg} / \mathrm{L}$, respectively. The highest sulphate concentration $(5.56 \mathrm{mg} / \mathrm{L})$ is observed at the surface level. There is almost no fluoride concentration except at the surface and $25 \mathrm{~cm}$ depth $(0.06 \mathrm{mg} / \mathrm{L}$ and $0.12 \mathrm{mg} / \mathrm{L})$. In the drilled well which has $3.42 \mathrm{~m}$ of depth to water table and the well depth of 4.5 $\mathrm{m}$, chloride concentration is $15.52 \mathrm{mg} / \mathrm{L}$ whilst nitrate concentration is zero.

In monitoring-2, the highest level of chloride and nitrate concentration $(320.00 \mathrm{mg} / \mathrm{L}$ and $106.72 \mathrm{mg} / \mathrm{L}$, respectively) could be found at the surface level. However, nitrate concentration in water is safe for human consumption below $45 \mathrm{mg} / \mathrm{L}$ (USEPA, 1980). The impact of fertilizer after monitoring-1 is seen quite clearly in the extracted water content. The sulphate concentration also is increased drastically (207.58 $\mathrm{mg} / \mathrm{L}$ ). The nitrate concentration level decreases with depth. Meanwhile, the chloride concentration decreases for each sample depth until a depth of $75 \mathrm{~cm}$ and increases slightly at a depth of $100 \mathrm{~cm}$. Average chloride and nitrate concentrations from the surface to a depth of $100 \mathrm{~cm}$ are $138.82 \mathrm{mg} / \mathrm{L}$ and $37.66 \mathrm{mg} / \mathrm{L}$ respectively. The values are completely different from the results of monitoring-1. Average values for both chloride and nitrate from the surface to a depth of 100 $\mathrm{cm}$ are increased around 9.98 and 3.50 times larger than monitoring-1 respectively. Meanwhile, in the drilled well (TBW 4.5), nitrate concentration also is observed to increase drastically. This result is believed to be from the direct pollution of the surface. This was because the surface water was seeping into the water table through a gap between the well wall and the well casing, although the gap had been filled with soil before. This is supported by the situation whereby there was no existence of any soil between the well wall and the well casing when monitoring- 2 was done. For the next monitoring, no water was taken from the well. However, cations content is relatively similar compared to monitoring-1, as no significant changes are found in monitoring-2.

In monitoring-3, the nitrate concentration level is still the highest value $(122.48 \mathrm{mg} / \mathrm{L})$ at the surface and even larger than the concentration in monitoring- 2 . The nitrate concentration is reduced gradually with depth. Meanwhile, the highest value of chloride $(160.00 \mathrm{mg} /$
L) is observed at a depth of $25 \mathrm{~cm}$ and decreases gradually with increasing depth. The sulphate concentration level is highest $(71.54 \mathrm{mg} / \mathrm{L})$ on the surface level. The average chloride and nitrate content are $81.02 \mathrm{mg} / \mathrm{L}$ and $36.52 \mathrm{mg} / \mathrm{L}$, which are around 0.58 and 0.97 times less than monitoring-2, respectively, whilst cations content still is relatively similar compared to the previous two surveys.

In monitoring-4, chloride and nitrate concentrations are still the highest to be observed at the surface and reduced gradually with depth. Meanwhile the sulphate concentration shows no significant value anymore. The average chloride concentration is $19.20 \mathrm{mg} / \mathrm{L}$, which is around 1.37 times higher than that for monitoring-1. Meanwhile the average nitrate concentration is 21.82 $\mathrm{mg} / \mathrm{L}$, which is around 2.03 times higher than that for monitoring-1.

Monitoring-5 is the last survey. Here, other than for depth from surface level to $100 \mathrm{~cm}$ depth, extracted water chemical analyses were performed at a depth of $150 \mathrm{~cm}$ and $200 \mathrm{~cm}$. The two highest values of nitrate concentration $(15.5 \mathrm{mg} / \mathrm{L})$ were found at the surface level and at the fourth sampling depth $(14.12 \mathrm{mg} / \mathrm{L})$. Meanwhile the highest concentration of chloride (22.76 $\mathrm{mg} / \mathrm{L}$ ) exists at the surface level and decreases gradually with depth. The sulphate concentration level has no significant value for all sample depths except for sample TBK, which the soil water sample at the anomaly zone observed after the geoelectrical survey. Average chloride and nitrate concentrations from the surface level to a depth of $100 \mathrm{~cm}$ are $15.02 \mathrm{mg} / \mathrm{L}$ and $13.38 \mathrm{mg} / \mathrm{L}$, respectively. These values are more or less equal to monitoring-1. For the cations content, they generally are relatively similar for every time lapse measurement.

\section{Geoelectrical model result}

The geoelectrical model of all monitoring survey is given in Fig. 2. In monitoring-1, visually, an average resistivity value of around $1900 \mathrm{ohm} . \mathrm{m}$ is observed at the surface. This value is also supported by direct surface resistivity measurement of 10 random point locations which have an average of $2100.03 \mathrm{ohm} . \mathrm{m}$ with standard deviation of $245.84 \mathrm{ohm} . \mathrm{m}$. In both geoelectrical models (TMB11 and TBM12), no significantly lower resistivity values appear from the surface level to a depth of $1 \mathrm{~m}$. The measured water table was $3.60 \mathrm{~m}$ below the ground surface in the borehole which was drilled at the $19 \mathrm{~m}$ mark of line 
Depth itration 20 RMS erorr $=4.0 \%$

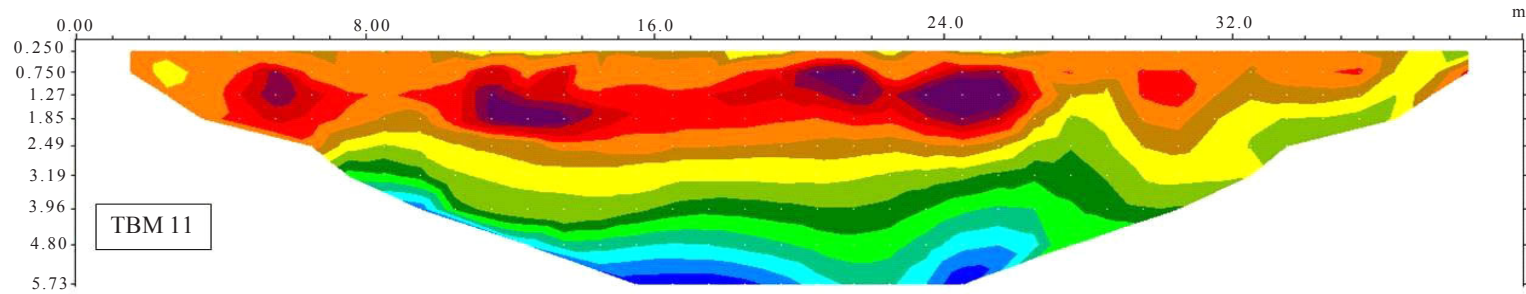

Depth itration 21 RMS erorr $=1.29 \%$

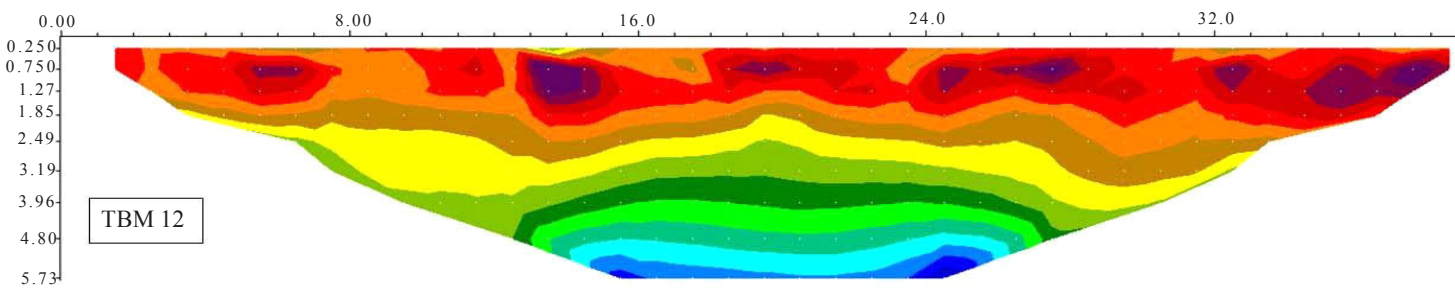

Depth itration 21 RMS erorr $=4.0 \%$

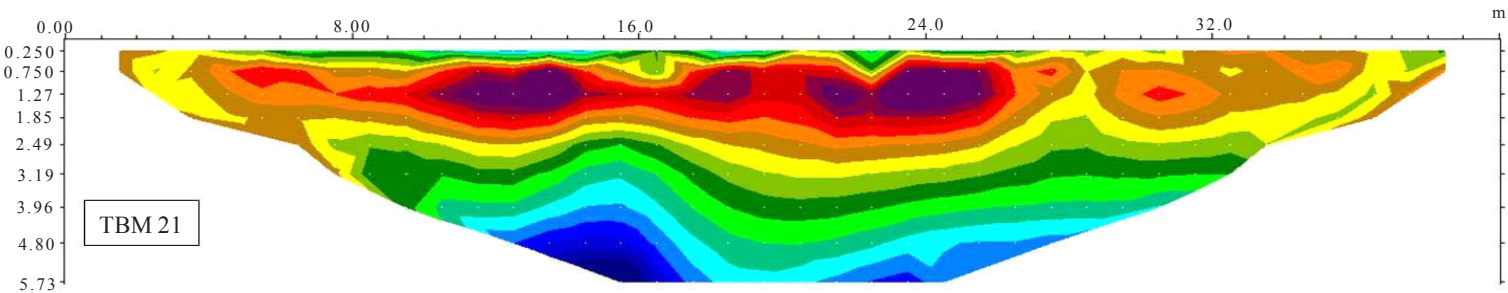

Depth itration 21 RMS erorr $=3.0 \%$

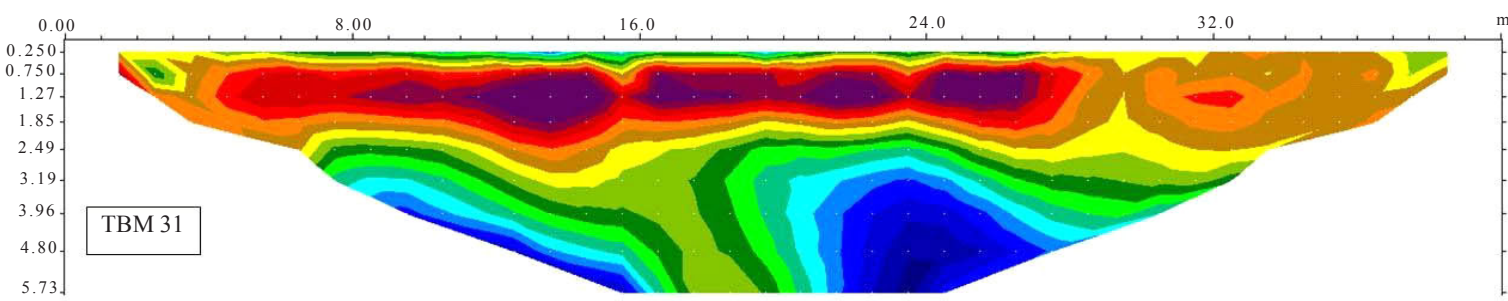

Depth itration 19 RMS erorr $=5.1 \%$

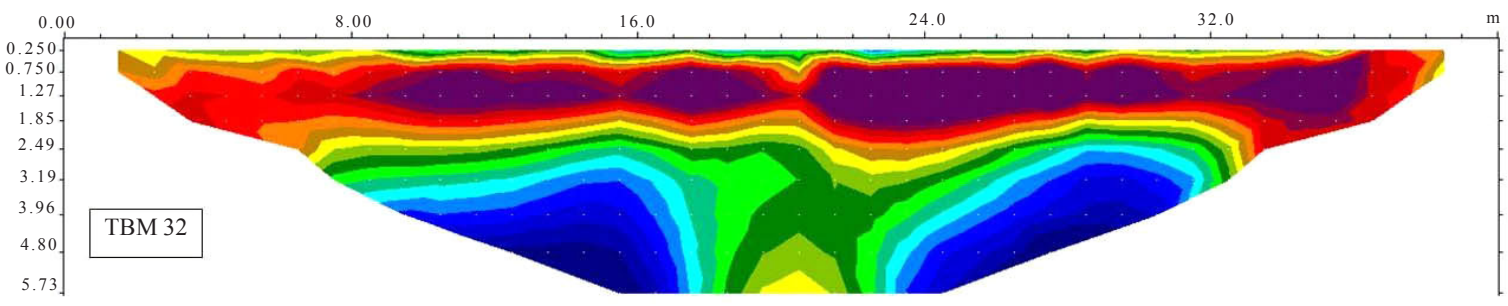

Depth itration 21 RMS erorr $=3.4 \%$

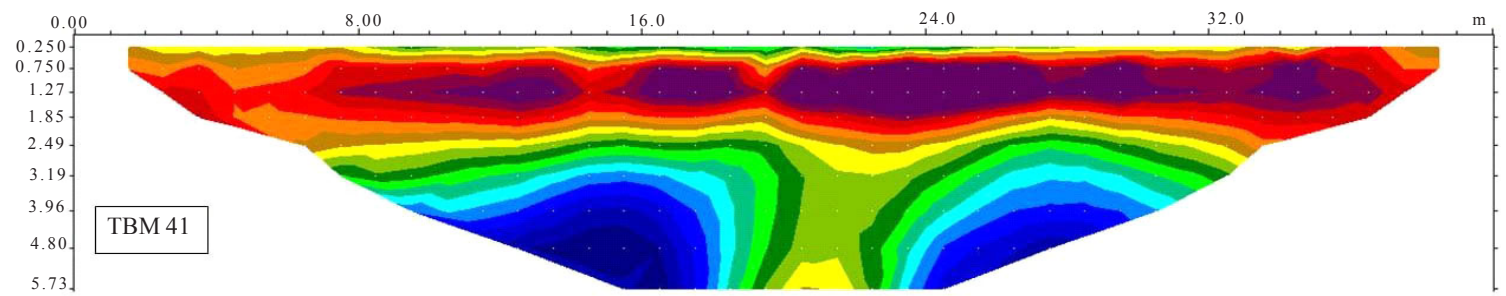

Fig. 2: Resistivity model for all monitoring survey 


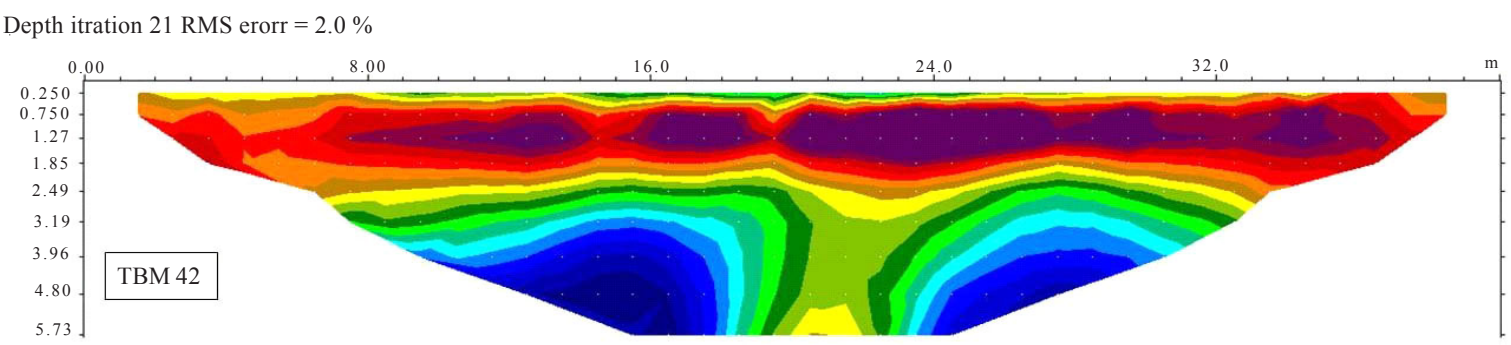

Depth itration 21 RMS erorr $=2.8 \%$

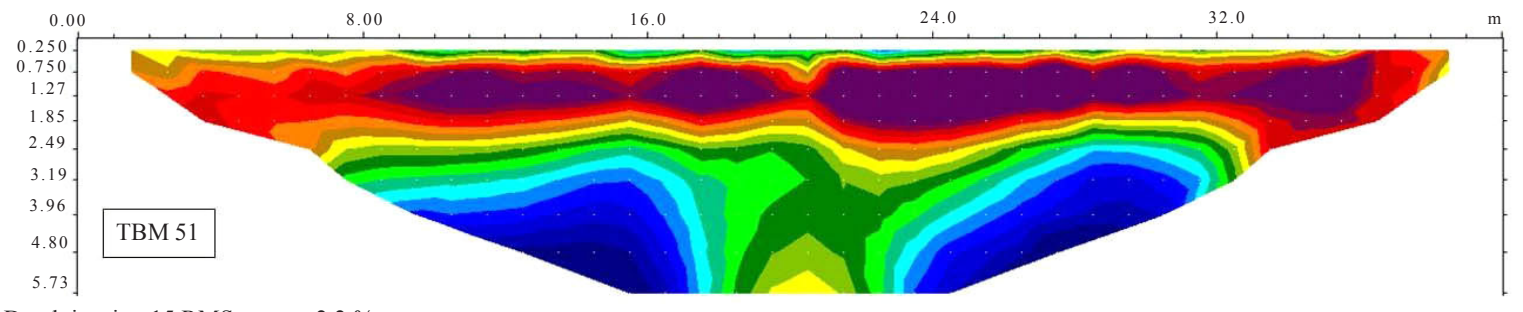

Depth itration 15 RMS erorr $=2.2 \%$
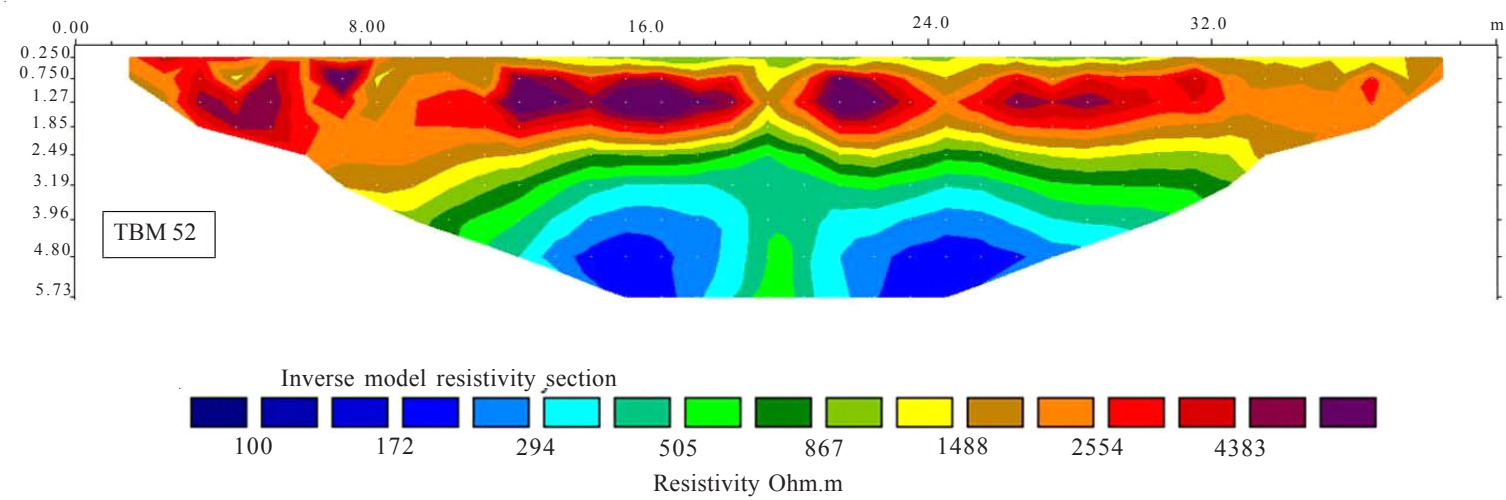

Fig. 2: (continued): Resistivity model for all monitoring survey

TBM11. In the geoelectrical model along line TBM11, resistivity values of approximately $500 \mathrm{ohm} . \mathrm{m}$ corresponded to a unit of compact sand fully saturated. In monitoring-2, only one line (TBM21) was conducted because of equipment's (Terrameter) technical problems. It could not be used after surveying line TBM21. There was no connection between the Terrameter and current selector box. The geoelectrical model of line TBM21 shows significantly reduced resistivity values on the surface within the fertilized zone (6-27 m mark) compared to the non-fertilized zone. The average surface resistivity value is about $400 \mathrm{ohm} . \mathrm{m}$ within the fertilized zone. The values also are supported by five points of direct surface resistivity measurement in the fertilized zone, with average of $437.00 \mathrm{ohm} . \mathrm{m}$ and standard deviation of 78.72 ohm.m. Below the 17-19 m mark from $2.5 \mathrm{~m}$ depth, it can be noticed that resistivity values are relatively higher than in the surrounding area. Other features still are relatively consistent to the previous survey (monitoring$1)$.

In the geoelectrical model of line TBM31 and line TMB32 (monitoring-3), relatively lower resistivity values still can be observed on the surface within the fertilized area (6-27 m mark). The value is around 0.4 times lesser than in the non-fertilized zone. Below the $17 \mathrm{~m}$ mark of starting $2.5 \mathrm{~m}$ depth, it can be seen that resistivity values are relatively higher than the surrounding area.

In monitoring-4, relatively lower resistivity value in geoelectrical model of lines TBM41 and TBM42 still can be found in the fertilized zone, as in monitoring- 3 . The existence of relatively higher resistivity values still appear in the same position as previous monitoring.

In the last survey (monitoring-5), resistivity values at the fertilized zone are not obviously different 
Int. J. Environ. Sci. Tech., 8 (4), 765-780, Autumn 2011

Table 3: Statistical values of extracted geoelectrical model (surface) for all monitoring and chemical pore water

\begin{tabular}{|c|c|c|c|c|c|c|c|c|c|c|c|c|c|}
\hline \multirow{2}{*}{$\begin{array}{c}\text { Line } \\
\text { ID }\end{array}$} & \multicolumn{4}{|c|}{ Fertilizer zone } & \multicolumn{4}{|c|}{ Non-fertilizer zone } & \multirow{2}{*}{$\begin{array}{r}\text { Moisture } \\
(\%)\end{array}$} & \multirow{2}{*}{$\begin{array}{c}\text { Chloride } \\
\mathrm{mg} / \mathrm{L}\end{array}$} & \multirow{2}{*}{$\begin{array}{c}\text { Nitrate } \\
\mathrm{mg} / \mathrm{L}\end{array}$} & \multirow{2}{*}{$\begin{array}{c}\text { Sulphate } \\
\mathrm{mg} / \mathrm{L}\end{array}$} & \multirow{2}{*}{$\begin{array}{c}\text { Total } \\
\text { anion } \\
\mathrm{mg} / \mathrm{L}\end{array}$} \\
\hline & Mean & S.D. & $\operatorname{Max}$ & Min & Mean & S.D. & Max & Min & & & & & \\
\hline TBM11 & 2040.23 & 582.44 & 2835.5 & 1129.5 & 2160.73 & 986.98 & 5276.8 & 1494.7 & 13.04 & 21.31 & 12.926 & 5.56 & 39.796 \\
\hline TBM21 & 443.18 & 256.6 & 1131.2 & 253.44 & 1253.14 & 475.39 & 2074.8 & 592.02 & 18.07 & 320 & 106.722 & 207.576 & 634.298 \\
\hline TBM31 & 515.85 & 160.35 & 814.01 & 222.7 & 1232.33 & 473.42 & 1992 & 514.78 & 18.85 & 92 & 122.482 & 71.548 & 286.03 \\
\hline TBM41 & 786.76 & 244.9 & 1337.1 & 344.16 & 1505.25 & 476.2 & 2312 & 748.99 & 16.99 & 26.48 & 26.642 & 12.33 & 65.452 \\
\hline TBM51 & 1093.48 & 336.76 & 1647.2 & 623.69 & 1509 & 442.51 & 2201.9 & 768.87 & 15.12 & 22.76 & 15.498 & 5.492 & 43.75 \\
\hline Line & \multicolumn{4}{|c|}{ Fertilizer zone } & \multicolumn{4}{|c|}{ Non-fertilizer zone } & Moisture & Chlo & Nitrate & Sulphate & Total \\
\hline ID & Mean & S.D. & Max & Min & Mean & S.D. & $\operatorname{Max}$ & Min & $(\%)$ & $\mathrm{mg} / \mathrm{L}$ & $\mathrm{mg} / \mathrm{L}$ & $\mathrm{mg} / \mathrm{L}$ & $\mathrm{mg} / \mathrm{L}$ \\
\hline TBM12 & 2026.74 & 535.25 & 3175.8 & 866.13 & 2268.61 & 427.1 & 2769.6 & 1539.2 & 13.04 & 21.31 & 12.926 & 5.56 & 39.796 \\
\hline TBM22 & & N.D.* & & & & N.D. & & & 18.07 & 160.00 & 53.36 & 103.79 & 317.15 \\
\hline TBM32 & 509.02 & 253.01 & 1112.1 & 207.47 & 1318.27 & 1079.67 & 3875.3 & 819.86 & 18.85 & 92 & 122.482 & 71.548 & 286.03 \\
\hline TBM42 & 810.16 & 298.33 & 1446.4 & 382.08 & 1487.3 & 698.96 & 3008.8 & 1060.7 & 16.99 & 26.48 & 26.642 & 12.33 & 65.452 \\
\hline TBM52 & 1016.82 & 624.41 & 2224.7 & 350.81 & 1502.13 & 395.94 & 1864.4 & 577.38 & 15.12 & 22.76 & 15.498 & 5.492 & 43.75 \\
\hline
\end{tabular}

*ND: Not detectable

compared to the non-fertilized zone (TBM51 and TBM52). However in some places, the lower resistivity still appears on the surface of the fertilized zone. In both geoelectrical models TBM51 and TBM52, the relatively lower resistivity value (coloured yellow) can be seen clearly at the deeper depth $(75 \mathrm{~cm})$ - at the zone where the previous survey was not found. The other two features are interesting anomalies revealed in the geoelectrical model TBM51. The zone with relatively lower resistivity value is observed at around $75 \mathrm{~cm}$ depth below 10 and $15 \mathrm{~m}$ marks in the section. This corresponds to the more porous and more permeable zone filled by pore water, which is composed of anions concentration. The extracted water chemical result derived from the zone ( $75 \mathrm{~cm}$ depth, $10 \mathrm{~m}$ mark) indicates that higher nitrate concentration is found in the zone (TBK in Table 2)

Overall, for the entire survey from monitoring- 2 to monitoring-5, lower resistivity values appear on the surface within the fertilized zone. Increasing resistivity values near the surface were obtained for third, fourth and fifth measurements compared to the second measurements. In the last survey (monitoring-5), although the resistivity value in the fertilized zone still is lower than in the non-fertilized zone, the difference is not too great. The decreasing resistivity value at the near surface within the fertilized zone is due to the nitrate and chloride anion concentration. The negative charges of anion content caused a decrease of the medium's resistivity (Islami, 2010a). Other researchers who study on the coastal plain also found that a small amount of anion content (e.g., chloride) in the aquifer due to occurrence of brackish water also can increase water conductivity value (Abdul Nassir et al., 2000; Leroux and Dahlin, 2006; Samsudin et al., 2007). Conductivity is inversely proportional to resistivity. In monitoring- 2 to monitoring-5, a new feature can be found below the $20 \mathrm{~m}$ mark of TBM 2 and below the $17.5 \mathrm{~m}$ mark of TBM 1 . The relatively higher resistivity value is seen at the position in each geoelectrical model. This feature is believed to be an effect of the existing vertical borehole with $4.5 \mathrm{~m}$ depth. The borehole position is around $20 \mathrm{~cm}$ from the TBM_2 at $20 \mathrm{~m}$ mark, and $40 \mathrm{~cm}$ away from the TBM_1 at $17.5 \mathrm{~m}$ mark.

The correlation of extracted water chemical content, soil moisture content and the geoelectrical resistivity model

Table 3 shows statistical values of the extracted geoelectrical model for both monitoring lines and chemical content of soil pore water at the surface level.

The highest average resistivity value is observed in monitoring-1, in which TBM11 and TBM12 have 2040.23 ohm.m and 2026.74 ohm.m, respectively. Moisture content is lowest (13.04 \%) in monitoring-1 among the next monitoring, while total anion is found to be $39.80 \mathrm{mg} / \mathrm{L}$. In monitoring-2, average resistivity of TBM 21 decreases $78.28 \%$ compared to monitoring1 in the fertilized zone, while in the non-fertilized zone, resistivity values decrease $42.00 \%$. The decreasing resistivity value in the non-fertilized zone is due to a $38.57 \%$ increase of moisture content. The bigger 
Table 4: Correlation of modelled geoelectrical resistivity with soil properties

\begin{tabular}{lllllll}
\hline & & & Fertilized zone & Non-fertilized zone \\
\cline { 2 - 7 } & $\begin{array}{l}\text { Resist and } \\
\text { moisture }\end{array}$ & $\begin{array}{l}\text { Resist and total } \\
\text { anion }\end{array}$ & $\begin{array}{l}\text { Resist and } \\
\text { nitrate }\end{array}$ & $\begin{array}{l}\text { Resist and } \\
\text { chloride }\end{array}$ & $\begin{array}{l}\text { Resist and } \\
\text { sulphate }\end{array}$ & Resist and moisture \\
\hline Correlation & -0.95 & -0.61 & -0.71 & -0.52 & -0.61 & -0.91 \\
\hline
\end{tabular}

resistivity decrease in the fertilizer zone $(78.28 \%)$, besides the impact of increasing moisture content, also is because of the increasing of total anion in pore water $(1493.87 \%)$. Thus, total anion increases around $1493 \%$ and it can decrease soil resistivity of around $36 \%$.

In monitoring-3, average resistivity values within the fertilized zone increase $16.40 \%$ compared to monitoring-2; however there still are decreases of 74.71 $\%$ and $74.88 \%$ compared to monitoring- 1 for TBM31 and TBM32, respectively. Total anion in pore soil water increases to be only $618.74 \%$ (compared $1493.87 \%$ in monitoring-2) and moisture content in monitoring-3 increases $4.31 \%$ more than monitoring- 2 . This means that the resistivity value in monitoring- 3 is not too big as its decrease. The average resistivity value in the area out of the fertilized zone decreases $42.96 \%$ and $41.89 \%$ for TBM31 and TBM32, respectively. These decreasing values in monitoring-3 for the non-fertilized zone are similar to the decrease in monitoring- 2 .

In monitoring-4, moisture content decreases from $18.85 \%$ in monitoring- 3 to $16.99 \%$ in monitoring- 4 . This causes the resistivity values in the non-fertilized zone to increase from $1232.33 \mathrm{ohm} . \mathrm{m}$ (TBM31) to 1505.25 ohm.m (TBM41) and 1318.27 (TBM32) ohm.m to $1487.30 \mathrm{ohm} . \mathrm{m}$ (TBM42), respectively. In the fertilized zone, resistivity values increase from $515.85 \mathrm{ohm} . \mathrm{m}$ to $786.76 \mathrm{ohm} . \mathrm{m}$ and $509.02 \mathrm{ohm} . \mathrm{m}$ to $810.16 \mathrm{ohm} . \mathrm{m}$ for TBM31 and TBM32, respectively. Again, anion content causes a $61.39 \%$ decrease of resistivity value in the fertilized zone.

In the last survey, average resistivity values within the fertilized zone decrease $46.40 \%$ and $49.82 \%$ for TBM51 and TBM52, respectively, compared to TBM11 and TBM12. Moisture content increases $15.95 \%$ and total anion increases $9.93 \%$. In the nonfertilized zone, the resistivity value only increased around $32 \%$. Generally, the occurrence of increasing anions content in pore soil water ranging from 10 $1500 \%$ has decreased soil resistivity value from $50 \%$ to $80 \%$.
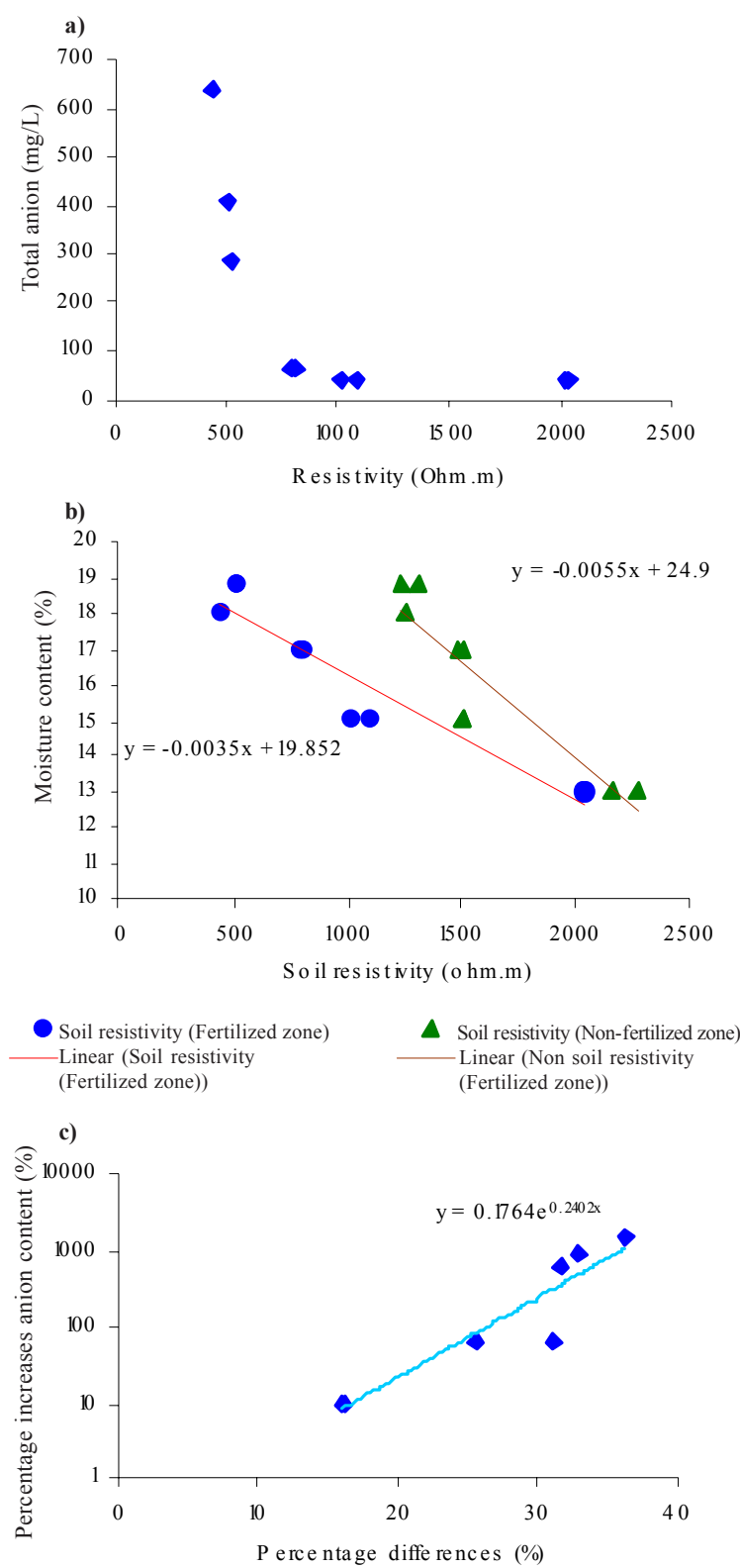

Fig 3: Total anion content versus soil resistivity within fertilized zone (a). Moisture content versus soil resistivity (b). Increases anion content against percentage differences between soil resistivity in non-fertilized and fertilized zone (c) 

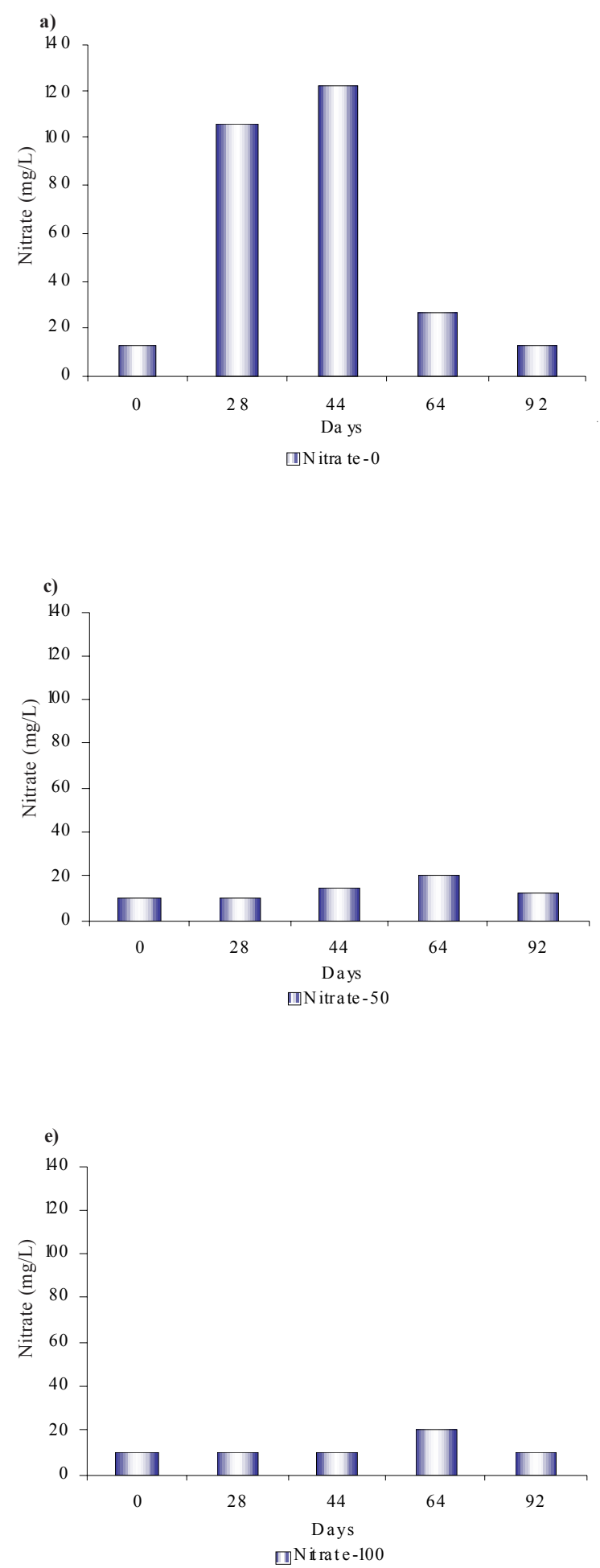

Fig. 4: Nitrate concentration levels $(\mathrm{mg} / \mathrm{L})$ at $\mathrm{Y}$ axis versus time (survey days) at $\mathrm{X}$ axis for each sampling depth (a) surface, (b) $25 \mathrm{~cm}$, (c) $50 \mathrm{~cm}$, (d) $75 \mathrm{~cm}$, (e) $100 \mathrm{~cm}$
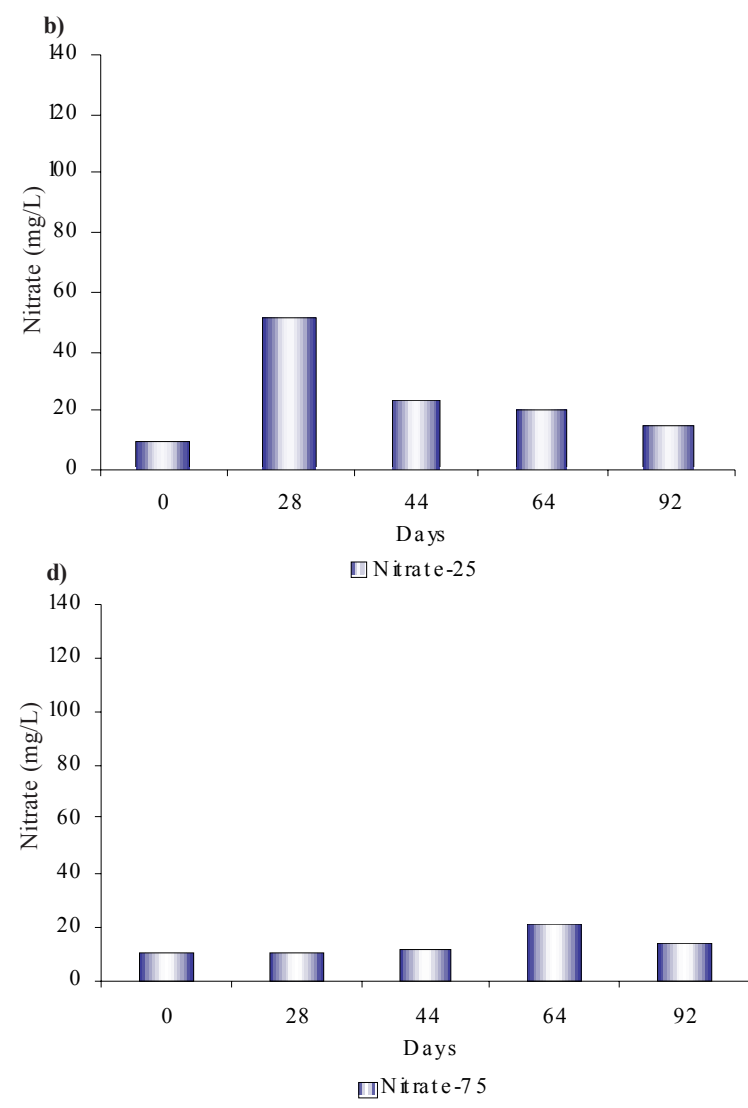

Finally, measurements of geoelectrical resistivity correlate significantly with soil properties with respect to the measured soil moisture content and chemical pore soil water (Table 4). Interpretations were given only for the comparable depth intervals of soil sampling and geoelectrical resistivities. The correlation of resistivity and moisture content within fertilized zone using Pearson product-moment correlation (Till, 1974) is -0.95 . The highest negative correlation implies higher moisture content, resulting in lower soil resistivity value. Resistivity and total anion content has a negative correlation of -0.61 , of which resistivity and sulphate, resistivity and chloride and resistivity and nitrate correlate $-0.61,-0.52$ and -0.71 , respectively. Moreover, within the non-fertilized zone, the correlation between resistivity and soil moisture content is -0.91 . However, a value of correlation more than 0.7 indicates a high probability of correlation (Taylor, 1997). Relatively lower correlation between resistivity value within the fertilized zone and total anion content is due to an increase in total anion content with a power trend of soil resistivity value (Fig. 3a). 

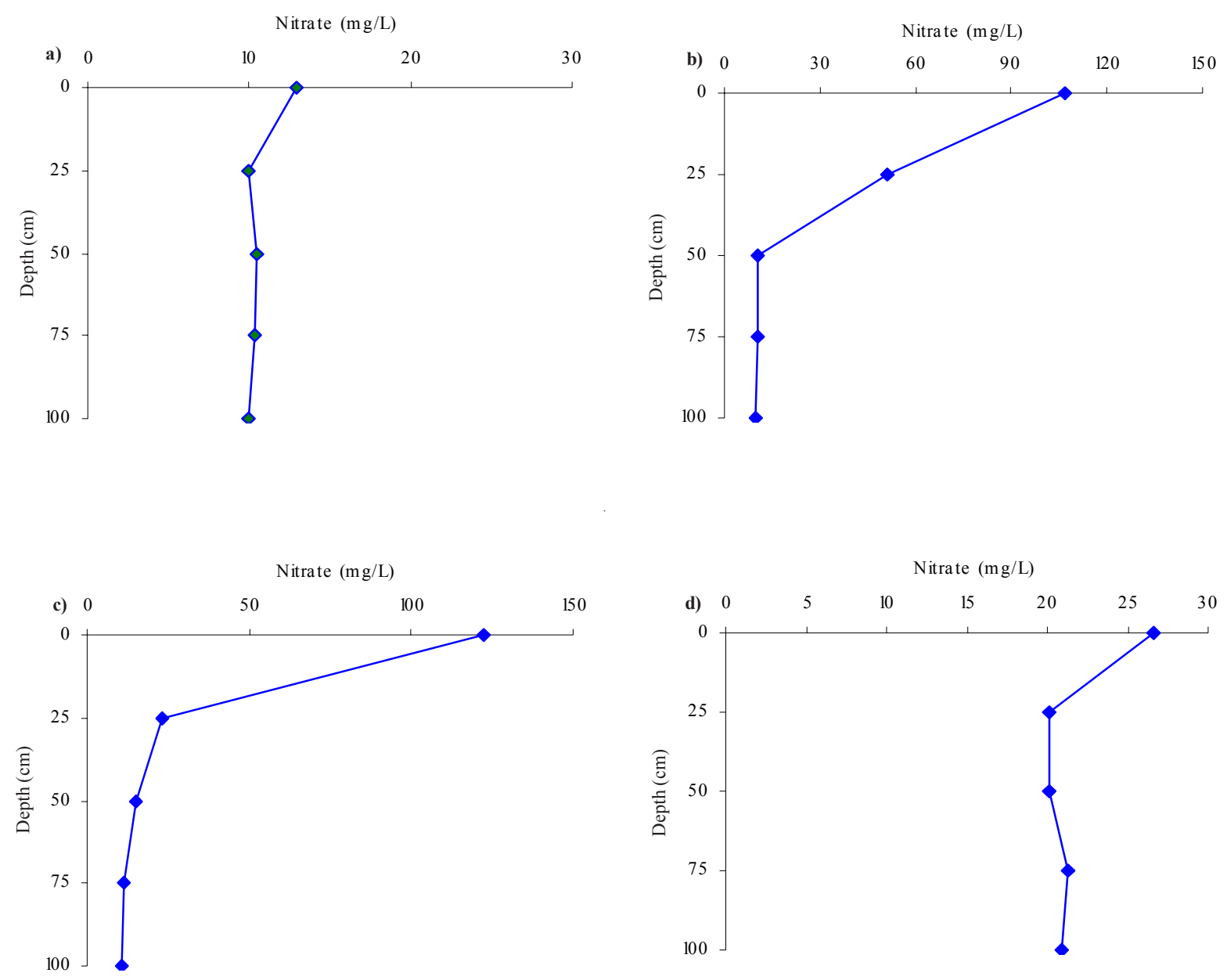

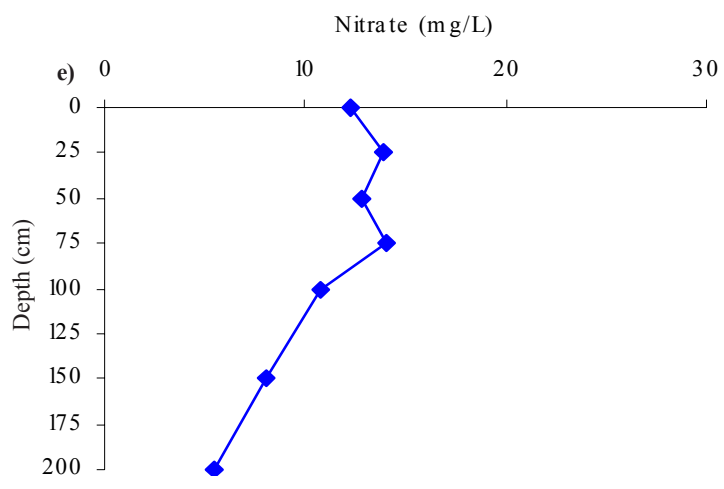

Fig. 5: Nitrate concentration $(\mathrm{mg} / \mathrm{L})$ versus sampling depth (cm) for each monitoring, (a) Monitoring-1, (b) Monitoring-2, (c) Monitoring-3, (d) Monitoring-4, (e) Monitoring-5

30
Meanwhile, soil moisture content has a linear trend with resistivity value (Fig. 3b). Moreover, it can be seen that anion content in pore soil water has increased correlation significantly between resistivity in the fertilized zone and moisture content, from -0.91 to 0.95 . This means that the anion content in pore soil water decreases soil resistivity significantly. Fig. 3c shows the increasing percentage of anion content versus percentage differences between soil resistivity in non-fertilized and fertilized zones. In Fig. 3c, a power trend has been observed when the pore soil water increased its anion content range from $10-1500 \%$ so that the resulting lower resistivity value differs from $16-36 \%$.

\section{Nitrate movement}

Fig. 4 shows a graph of nitrate concentration levels 


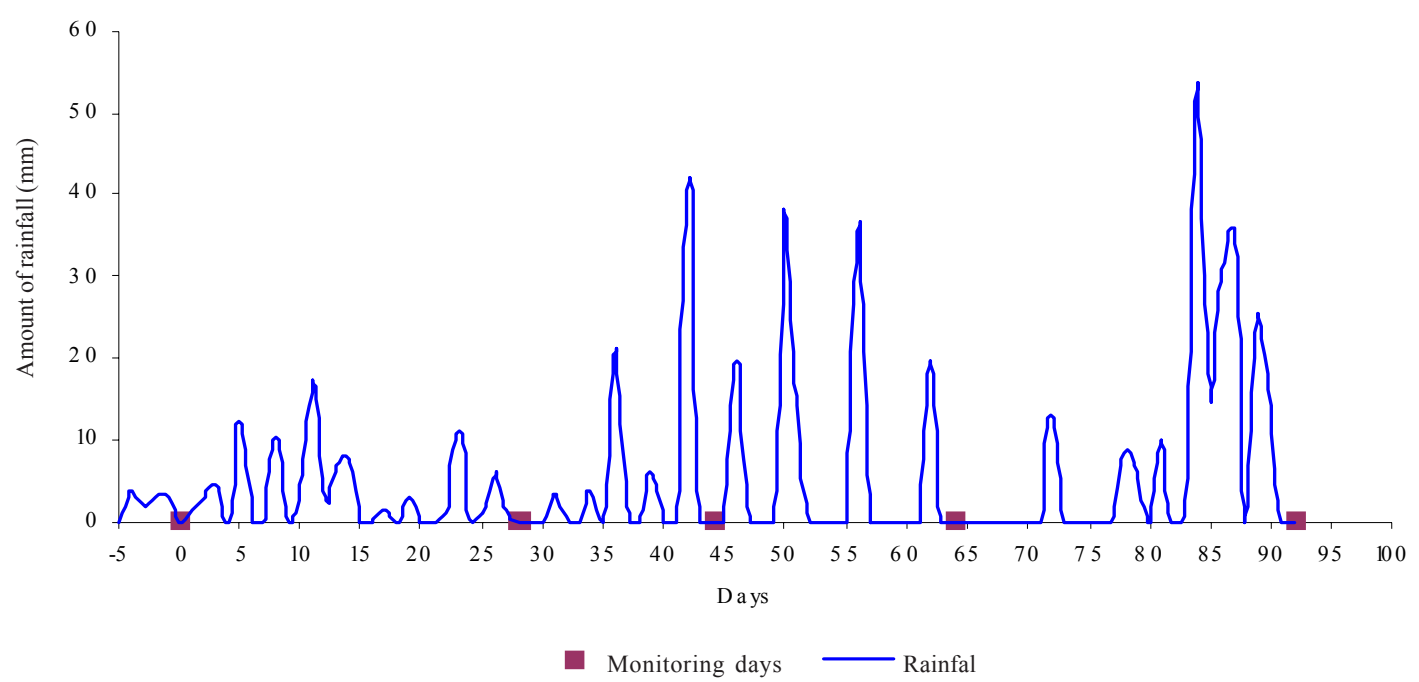

Fig. 6: Amount of rainfall during the monitoring survey

for each depth of sampling versus time lapse monitoring (survey days). The maximum nitrate concentration on the surface happens in 44 days (monitoring-3) after the introduction of the chemical fertilizer to the site. The maximum nitrate concentration at the depth of $25 \mathrm{~cm}$ happens after 28 days (monitoring-2), as shown in Fig. 5.b. The nitrate concentration increases significantly in monitoring-2 compared to monitoring-1 (before fertilizer introduction). Then, it decreases almost linearly with increases in sampling depth. Other researchers (Kaushal et al., 2005; Oelmann et al., 2007; Mirjat et al., 2008) also found the highest nitrate concentration at the near surface level depth. Meanwhile, for a depth of $50 \mathrm{~cm}, 75$ $\mathrm{cm}$ and $100 \mathrm{~cm}$, the maximum nitrate concentration values occur 64 days after the fertilizer was introduced (Figs. 4.c, $d$ and e).

Fig. 5 shows the nitrate concentration level versus depth of sampling for each monitoring survey. In monitoring-1, nitrate concentration hardly fluctuates, whilst in monitoring-2, nitrate concentration increases significantly on the surface and decreases linearly with depth until a depth of $50 \mathrm{~cm}$. In monitoring-3, a nitrate concentration has its highest level on the surface but decreases significantly with increasing depth. In monitoring-4, higher nitrate concentration values still are maintained on the surface. For the last survey (monitoring-5), the nitrate concentration levels are not as high as monitoring-1. Silva et al. (2005) reported that soil hydrological properties (e.g., water flux, moisture content) were found more important to explain different magnitudes of nitrate leaching losses.
The total amount of water inputs (rainfall) during the monitoring survey are shown in Fig. 6. Rainfall data was obtained from the nearest rainfall monitoring station (Pejabat Haiwan Jajahan Machang, around 8 $\mathrm{km}$ inland from the site). Total water inputs at the site between intervals of monitoring- 1 and monitoring-2, monitoring- 2 and monitoring- 3 , monitoring- 3 and monitoring- 4 , and monitoring- 4 and monitoring-5 comprised $92.5 \mathrm{~mm}, 75.9 \mathrm{~mm}, 127.7 \mathrm{~mm}$ and $212.4 \mathrm{~mm}$ of rainfall, respectively. Spray irrigation is not a common farming practice in the region. The rainfall amount that occurred during the monitoring period interval did not create much water in the pore soil. Soil moisture contents at a depth up to $100 \mathrm{~cm}$ showed temporal variations with a few days of rainfall.

Based on Fig. 6, and Table 2, there was no significant correlation between the amounts of nitrate concentration with rainfall and with apparent water content in the pore soil (moisture content). The highest moisture content on the surface can be found in monitoring-2, whereas the highest nitrate concentration revealed was in monitoring-3 at the same location. Furthermore, in Fig. 6, it is noted that there are high rates of rainfall between monitoring- 3 and monitoring4 and also between monitoring- 4 and monitoring- 5 that cause the nitrate concentration for a depth of 100 $\mathrm{cm}$ to decrease significantly. The result in this research supports the study that was done by Silva et al. (2005). He said that the water flux is more important for nitrate leaching. 


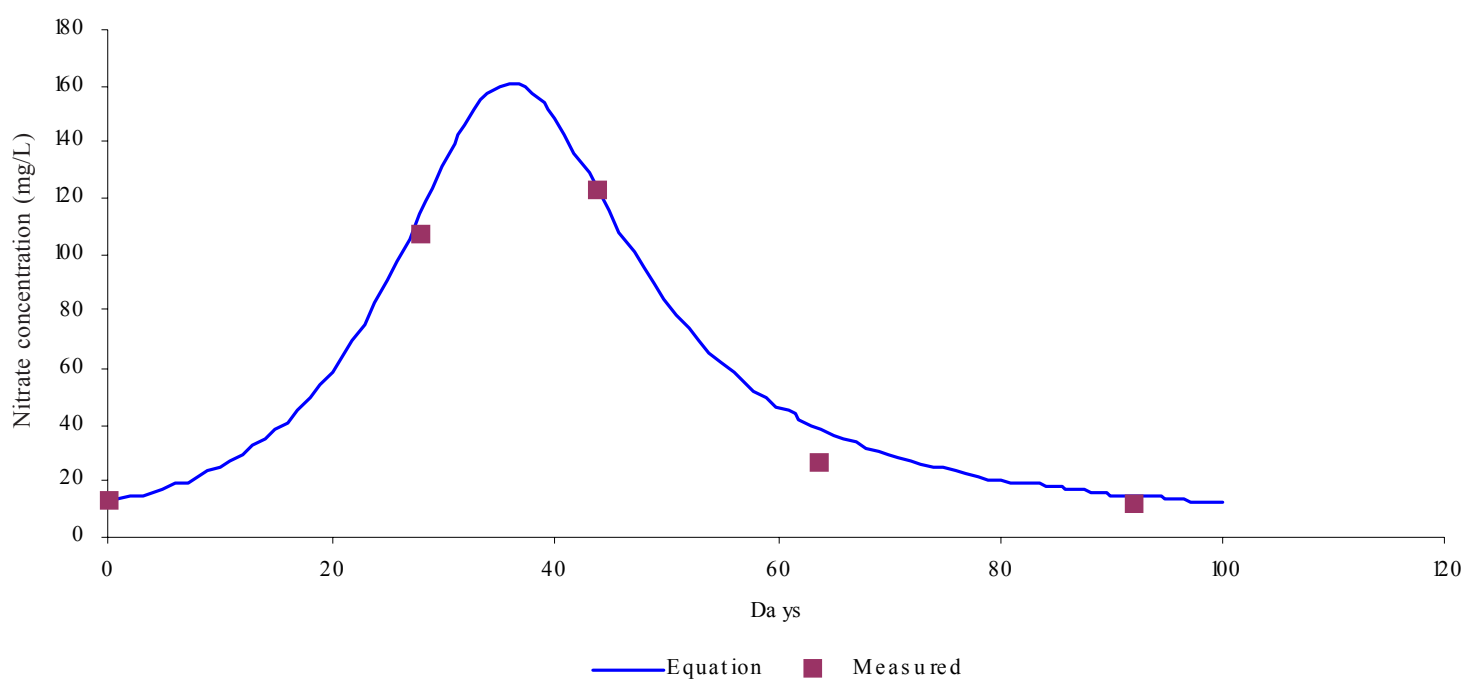

Fig. 7: Nitrate concentration at around the surface level

In conjunction with the nitrate concentration in pore soil, the ammonia and nitrite-oxidising bacteria need to be considered. According to Lee et al. (2006), presence of oxygen by the autotrophic ammonia-oxidising bacteria (the major genera is Nitrosomonas) can cause ammonia to be oxidised to nitrite $\left(\mathrm{NO}^{2-}\right)$ faster. In the next step, due to the nitrite being a rather unstable nitrogen species, the autotrophic nitrite-oxidising bacteria (the true nitrifying bacteria with major genera is Nitrobacter) oxidise nitrite to nitrate $\left(\mathrm{NO}^{3-}\right)$. However, in this study, the amount of these bacteria is not determined and not questioned.

The distribution pattern of nitrate on the surface, as given in Fig. 4a, is similar to non-monotonic function (Andrews, 1986). Using Wolfram Mathematica 7 software, the predicted equation for nitrate concentration ( $N c$ with unit in $\mathrm{mg} / \mathrm{L}$ ) at the surface is developed as the following equation:

$$
N c=\frac{\alpha+\beta . D}{1.088-\gamma . . D+\delta . D^{2}}
$$

Where $\alpha$ is initial nitrate concentration before fertilizer application $(\mathrm{mg} / \mathrm{L}), \beta$ is constant $(0.264494)$, $D$ is days monitoring (no unit), $\gamma$ is constant $(0.0541654)$ and $\delta$ is constant ( 0.00077287$)$.

In order to see the correlation between the developed equation above (predicted nitrate concentration on the surface) with measured nitrate concentration data, the equation was plotted together with measured nitrate concentration in the same graph (Fig. 7). Visually, in Fig. 7, correlation between predicted and measured nitrate concentration on the surface is very good. It is supported by calculating their correlation to be 0.99 . Based on the predicted plot line from the equation, the maximum nitrate concentration is expected 36 days after fertilization. Moreover, the nitrate concentration will be at the initial concentration 100 days after fertilization. Regarding this finding, it can be concluded that the nitrate concentration will be above accepted limits for human consumption at a depth up to $1 \mathrm{~m}$. This happened starting from around 17-60 days after fertilization.

\section{CONCLUSION}

This study demonstrates the usefulness of geoelectrical resistivity, hydrogeochemical and soil properties analysis methods to monitor chemical fertilizer in sandy soil. Fife time lapse measurements were taken at about a month intervals. Resistivity measurements show a sharp decrease in resistivity value at the second measurement in the fertilized zone and a gradual increase to approximately the initial level at the last measurement. The decrease of the resistivity value in fertilized zone is complimented by a rise in nitrate content. The moisture content decrease with depth however the values remain almost the same in all the time lapse measurement. Hydrogeochemical data show that cation concentration does not exhibit any 
specific changes for each measurement. Furthermore, chloride and sulphate anion content decrease with power trend, starting from monitoring-2. However, nitrate anion shows a nonmonotonic trend. Nitrate concentration exhibits maximum concentration 36 days after fertilization and will return to initial values 100 days after the fertilization process in the semi-pervious soil. The measurements indicate that the integration of geoelectrical resistivity, hydrogeochemical and soil property analysis methods give improved result and resolution for chemical fertilizer monitoring.

\section{ACKNOWLEDGEMENTS}

The financial support through the Universiti Malaya (University of Malaya) research grants No. PJPFS308/ $2008 \mathrm{C}$ is gratefully acknowledged. Special thanks are due to the field crew and clerical staff of Department of Geology, Universiti Malaya, for assistance during the fieldwork and in the preparation of this paper.

\section{REFERENCES}

Abdul Nassir, S. S.; Loke, M. H.; Lee, C. Y.; Nawawi, M. N. M., (2000). Salt-water intrusion mapping by geoelectrical imaging surveys. Geophys. Prospect., 48 (4), 647-661 (15 pages).

Almasri, M. N.; Kaluarachchi, J. J., (2004). Assessment and management of long-term nitrate pollution of ground water in agriculture-dominated watersheds. J. Hydrol., 295, 225245 (21 pages).

Andrews, J. F., (1986). A mathematical model for the continuous cultures of microorganisms utilizing inhibitory substrates, Biotech. Bioeng., 10 (6), 707-723 (17 pages).

Atafar Z, Mesdaghinia A, Nouri J, Homaee, M.; Yunesian, M., (2010). Effect of fertilizer application on soil heavy metal concentration. Environ. Monitor. Assess. 160 (1-4), 83-89 (7 pages)

Baharuddin, M. F. T.; Hashim, R.; Taib, S., (2009). Electrical Imaging Resistivity Study at the Coastal Area of Sungai Besar, Selangor, Malaysia. J. Appl. Sci., 9 (16), 2897-2906 (10 pages).

Barker, R. D., (1981). Offset system of electrical resistivity sounding and its use with multicore cables. Geophys. Prospect., 29 (1), 128-143 (16 pages).

Bear, J., (1972). Dynamics of fluids in porous media, American Elsevier Pub. Co.

Bernhard, C.; Carbiener, R.; Cloots, A. R.; Froehlicher, R.; Schenk, C.; Zilliox, L., (1992). Nitrate pollution of groundwater in the Alsatian plain (France). A multidisciplinary study of an agricultural area: the central ried of the Ill river. Environ. Geol. Water Sci., 20 (2), 125137 (13 pages).

Black, C. A., (1965). Methods of soil analysis, Part 1: Physical and mineralogical properties. The American Society of Agronomy., 9. Madison, Wisconsin, USA.

Cobbing, E. J.; Pitfield, P. E. J., (1992). The Granites of the South-East Asian tin belt, British Geological Survey, Overseas Memoir 10.
Das, B. M., (2001). Principles of geotechnical engineering, fifth edition, California State University.

Griffiths, D. H.; Barker, R. D., (1993). Two-dimensional resistivity imaging and modelling in areas of complex geology. J. Appl. Geophys., 29 (3-4), 211-226 (16 pages).

Griffiths, D. H.; Turnbull, J.; Olayinka, A. I., (1990). Twodimensional resistivity mapping with a computer-controlled array. First Break., 8 (4), 121-129 (9 pages).

Islami,N.,(2010a). Geoelectrical Resistivity and Hydrogeochemical Contrast between the Area that Has Been Applied with Fertilization for Long Duration and NonFertilization. ITB. J. Eng. Sci., 42 (2), 151-164 (14 pages).

Islami, N.; Samsudin, T.; Yusoff, I., (2010b). Geoelectrical Resistivity and Hydrogeochemical Methods for Groundwater Investigation in the Agriculture Area: A Case Study from Machang - Malaysia, Full Paper (Proceeding) in International Symposium and The $2^{\text {nd }}$ AUN/SEED-Net Regional Conference on Geo-Disaster Mitigation in ASEAN. Bali, Indonesia 2526 February, 383-394 (12 pages).

Kaushal, K. G.; Madan, K. J.; Kar, S., (2005). Field Investigation of Water Movement and Nitrate Transport under Perched Water Table Conditions. Biosyst. Eng., 92 (1), 69-84 (16 pages).

Lee, M. S.; Kang-Kun, Lee, K. K.; Hyuna, Y.; Clement, T. P.; Hamilton, D., (2006). Nitrogen transformation and transport modeling in groundwater aquifers. Ecol. Model., 192, 143159 (17 pages).

Leroux, V.; Dahlin, T., (2006). Time-lapse resistivity investigations for imaging saltwater transport in glaciofluvial deposits. Environ. Geol., 49, 347-358 (12 pages).

Loke, M. H., (1999). Electrical imaging surveys for environmental and engineering studies. User's Manual for Res2dinv. Electronic version. http://www.geometrics.com.

Loke, M. H., (2007). Rapid 2-D Resistivity and IP inversion using the least-squares method, Geoelectrical Imaging 2D and 3D. GEOTOMO SOFTWARE, Malaysia. http:// www.geoelectrical.com.

Loke, M. H.; Barker R. D., (1996). Rapid least-squares inversion of apparent resistivity pseudo sections using a quasi-Newton method. Geophys. Prospect., 44, 131-152 (22 pages).

Mahvi, A. H.; Nouri, J.; Babaei, A. A.; Nabizadeh. R., (2005). Agricultural activities impact on groundwater nitrate pollution. Int. J. Environ. Sci. Tech., 2 (1), 41-48 (8 pages).

Malaysian Meteorological Department (MMD)., (2009). Annual Report.

Mirjat, M. S.; Chandio, A. S.; Memon, S. A.; Mirjat, M. U., (2008). Nitrate Movement in the Soil Profile under Irrigated Agriculture: A Case Study. Agricultural Engineering International. The CIGR Ejournal. Manuscript LW 07024.

Noel, M.; Walker, R., (1990). Development of an electrical resistivity tomography system for imaging archeological structures. In: Pernicka, E.; Wagner, G.A. (Eds.), Archaeometry '90. Birkhauser, Base1, 767- 776 (10 pages).

Obire, O.; Ogan, A.; Okigbo, R. N., (2008). Impact of fertilizer plant effluent on water quality. Int. J. Environ. Sci. Tech., 5 (1), 107-118 (12 pages).

Oelmann, Y.; Kreutziger, Y.; Bol, R.; Wilcke, W., (2007). Nitrate leaching in soil: Tracing the $\mathrm{NO}_{3}^{-}$sources with the help of stable $\mathrm{N}$ and $\mathrm{O}$ isotopes. Soil Biol. Biochem., 39 (12), 3024-3033 (10 pages). 
Overmeeren van, R. A.; Ritsema, I. L., (1988). Continuous vertical electrical sounding. First Break., 6 (10), 313-324 (12 pages).

Reynolds, J. M., (1997). An Introduction to Applied and Environmental Geophysics. John Wiley and Sons, Chichester.

Saadi, Z.; Maslouhi, A., (2003). Modeling nitrogen dynamics in unsaturated soils for evaluating nitrate contamination of the Mnasra groundwater. Adv. Environ. Res., 7, 803823 ( 21 pages).

Saim, S., (1999). Groundwater protection in North Kelantan, Malaysia. SOURCE: Seminar on Water : Forestry and Landuse Perspectives. Kuala Lumpur, Malaysia 30-31 March. Paper 11.

Samsudin, A. R.; Haryono, A.; Hamzah, U.; Rafek, A. G., (2007). Salinity mapping of coastal groundwater aquifers using hydrogeochemical and geophysical methods: a case study from north Kelantan, Malaysia. Environ. Geol.,

Silva, R. G.; Holub, S. M.; Jorgensen, E. E.; Ashanuzzaman, A. N. M., (2005). Indicators of nitrate leaching loss under different land use of clayey and sandy soils in southeastern Oklahoma. Agriculture, Ecosyst. Environ., 109, 346-359
(14 pages).

Singh, B.; Singh, Y,; Sekhon, G. S., (1995). Fertilizer-N use efficiency and nitrate pollution of groundwater in developing countries. Contam Hydrol., 20, 167-184 (18 pages).

Taylor, J. R., (1997). An Introduction to Error Analysis. University Science Books, Sausalito, CA.

Till, R., (1974). Statistical methods for the earth scientist, The Macmillan Press Ltd.

U.S. EPA., (1980). Nitrogen-ammonia/nitrite/nitrate, water quality standards criteria summaries. GPO: 1980-341-082/ 107. Washington, DC.

World Health Organization (WHO)., (1984). Guideline for Drinking-Water, Vol. 1. Recommendations. World Health Organization, Geneva.

Yang, S. M.; Li, F. N.; Suo, D. R.; Guo, T. W., (2006). Effect of long-term fertilization on soil productivity and nitrate accumulation in Gansu Oasis. Agr. Sci. in China, 5 (1), $57-$ 67 (11 pages)

Zhang, H.; Dang, Z.; Zheng, L. C.; Yi, X.Y., (2009). Remediation of soil co-contaminated with pyrene and cadmium by growing maize (Zea mays L.). Int. J. Environ. Sci. Tech., 6 (2), 249258. (10 pages).

\section{AUTHOR (S) BIOSKETCHES}

Islami, N., PhD Student, Department of Geology, University of Malaya, Malaysia. Email: nris@um.edu.my

Taib, S., Ph.D., Associate Professor, Department of Geology, University of Malaya, Malaysia. Email: samsudin@um.edu.my

Yusoff, I., Ph.D., Associate Professor, Department of Geology, University of Malaya, Malaysia. Email: ismaily70@um.edu.my

Abdul Ghani, A., Ph.D., Professor, Department of Geology, University of Malaya, Malaysia. Email: azmangeo@um.edu.my

How to cite this article: (Harvard style)

Islami, N.; Taib, S.; Yusoff, I.; Abdul Ghani, A., (2011). Time lapse chemical fertilizer monitoring in agriculture sandy soil. Int. J. Environ. Sci. Tech., 8 (4), 765-780. 